\title{
Laboratory Culture of Hypsibius exemplaris
}

\author{
Robert McNuff ${ }^{1}$
}

Sciento, Whitefield, Manchester, M45 6TB, England, United Kingdom

I have reared a culture of the tardigrade Hypsibius exemplaris for 30 years, since 1987. Here, I present my culture protocol.

\section{MATERIALS}

It is essential that you consult the appropriate Material Safety Data Sheets and your institution's Environmental Health and Safety Office for proper handling of equipment and hazardous materials used in this protocol.

RECIPES: Please see the end of this protocol for recipes indicated by $<R>$. Additional recipes can be found online at http://cshprotocols.cshlp.org/site/recipes.

Reagents

Bold's basal medium plus soil extract $<\mathrm{R}>$

Chalkley's medium plus soil extract $<\mathrm{R}>$

Chlorococcum culture

Cultures of Chlorococcum can be sourced from Sciento (www.sciento.co.uk; catalog code A68).

Spring water

Use commercial bottled spring water found in grocery stores. Do not use tap water; the chlorine and/or chloramine common in tap water is harmful to many microscopic animals.

Tardigrades (Hypsibius exemplaris)

Cultures of $\mathrm{H}$. exemplaris can be sourced from Sciento (www.sciento.co.uk; catalog code Z151).

Equipment

Aluminum foil

Clingfilm or Parafilm (see Step 5)

Cotton wool (nonabsorbent)

Erlenmeyer flasks $(250 \mathrm{~mL})$

Fluorescent lights (with $40-\mathrm{W}$ tubes)

A timer for the lights is optional (see Steps 3 and 6).

Incubator for temperatures of $10^{\circ} \mathrm{C}-18^{\circ} \mathrm{C}$ (optional; see Steps 3 and 6)

Petri plates (6- $\mathrm{cm}$ diameter; glass or plastic)

${ }^{1}$ Correspondence: bob@sciento.co.uk

From the Emerging Model Organisms collection.

(C) 2018 Cold Spring Harbor Laboratory Press

Cite this protocol as Cold Spring Harb Protoc; doi:10.1101/pdb.prot102319 
I collected the original strain of Hypsibius exemplaris on November 13, 1987 from a benthic sample taken from a pond in Darcy Lever, Bolton, Lancashire, England (latitude 53.566166, longitude -2.3925272; British National Grid Ref. SD741078). The pond is typical of many in this reclaimed wetland area; it is surrounded by dense shrubs (e.g., Corylus and Erica) and marginal mosses (e.g., Polytrichum, Sphagnum, and Rhytidiadelphus spp.). H. exemplaris will grow on diverse algae, but for ease of culturing and strain stability, I have maintained my stock of $\mathrm{H}$. exemplaris on Chlorococcum spp. algae.

\section{Culture of Chlorococcum}

1. Add $150 \mathrm{~mL}$ of Bold's basal medium plus soil extract to each of several 250-mL Erlenmeyer flasks, and stopper the flasks with nonabsorbent cotton wool and aluminum foil. Autoclave for $20 \mathrm{~min}$ at $15 \mathrm{psi}$, and allow the flasks to stand for $24 \mathrm{~h}$.

Each flask, when harvested, will provide adequate algal food for sustaining 200 tardigrades over 4-6 wk.

2. After $24 \mathrm{~h}$, inoculate each flask with $<2 \mathrm{~mL}$ of a preexisting Chlorococcum culture.

3. Cover the flasks as described in Step 1, and leave them at room temperature (or between $15^{\circ} \mathrm{C}$ and $25^{\circ} \mathrm{C}$ ). Illuminate under fluorescent lighting (with 40 -W tubes) either continuously or controlled to give a photoperiod of $14 \mathrm{~h}$ of light and $10 \mathrm{~h}$ of darkness each day.

Agitating the flasks is not essential. The cultures will be ready to feed to the tardigrades after 4-6 wk. Chlorococcum cells are nonmotile and settle the bottom of the flasks, where concentrated cells can be collected by pipetting and used for standard culture (Steps 4-7) or small-scale culture (Steps 8-10) of H. exemplaris.

Chlorococcum cultures will perish if frozen; always keep them at room temperature. The cultures can be maintained indefinitely by subculturing as described in Steps 1-3 as necessary.

\section{Standard Culture of Hypsibius exemplaris}

4. Pour $150 \mathrm{~mL}$ of Chalkley's medium plus soil extract into a sterile 250-mL Erlenmeyer flask.

5. Add $\sim 3-5 \mathrm{~mL}$ of concentrated Chlorococcum cells to the flask, and inoculate with $1 \mathrm{~mL}$ of tardigrades or embryos. (Chlorococcum cells are nonmotile and can be pipetted from the bottom of the Chlorococcum flasks.) Seal the flask with clingfilm or Parafilm.

The seal prevents contamination from fungal spores and mites.

6. Place the flask in a cool $\left(10^{\circ} \mathrm{C}-20^{\circ} \mathrm{C}\right)$, shaded location, with continuous darkness or with a photoperiod of $14 \mathrm{~h}$ of light and $10 \mathrm{~h}$ of darkness each day.

7. Subculture every $4-6$ wk as necessary by repeating Steps $4-6$.

Optimal subculturing intervals are subject to temperature, algal food inoculum, and density of tardigrades. Cultures generally peak between 4 to 6 wk, after most of the algae have been grazed over. Microscopical observation of cultures for abundant tardigrades or the presence of eggs will reveal the best time for setting up and inoculating fresh culture media.

Old cultures can be kept in reserve if necessary by concentrating and storing in the refrigerator at $4^{\circ} \mathrm{C}$, where the tardigrades will survive for many months (or years) in an inactive or lethargic state.

\section{Small-Scale Culture of Hypsibius exemplaris}

Small-scale cultures consisting of hundreds of tardigrades per dish can be maintained indefinitely in commercial bottled spring water in glass (Gabriel et al. 2007) or plastic Petri plates. Tardigrades stick to plastic, but this can be avoided by precoating the plates with algae.

8. Pour $15 \mathrm{~mL}$ of spring water and $1 \mathrm{~mL}$ of Chlorococcum algal culture into a 6-cm-diameter Petri plate. If the Petri plate is plastic, incubate for several hours to overnight at room temperature before proceeding to Step 9.

9. Add $\sim 1 \mathrm{~mL}$ of tardigrade inocula into the Petri plate, cover with the Petri dish lid, and incubate in a shaded location at room temperature. 
10. Change algae and water every $10 \mathrm{~d}$ to $2 \mathrm{wk}$ as follows.

i. Gently pipette the algae and tardigrades up and down to loosen clumps.

ii. Allow the tardigrades to settle, and then pour out most of the water.

iii. Add $\sim 7 \mathrm{~mL}$ of spring water to the dish.

iv. Repeat Steps 10.i-10.iii four or five times.

v. After the last water change, add $1 \mathrm{~mL}$ of algal culture.

\section{RECIPES}

Bold's Basal Medium Plus Soil Extract

Solution

Reagent

Quantity

Stock solution 1

$\mathrm{NaNO}_{3}$

$10.0 \mathrm{~g}$

Stock solution 2

$\mathrm{H}_{2} \mathrm{O}$ (distilled)

$400 \mathrm{~mL}$

$\mathrm{MgSO}_{4} \cdot 7 \mathrm{H}_{2} \mathrm{O}$

$3.0 \mathrm{~g}$

$\mathrm{H}_{2} \mathrm{O}$ (distilled)

$400 \mathrm{~mL}$

Stock solution 3

$\mathrm{NaCl}$

$1.0 \mathrm{~g}$

Stock solution 4

$\mathrm{H}_{2} \mathrm{O}$ (distilled)

$400 \mathrm{~mL}$

$\mathrm{K}_{2} \mathrm{HPO}_{4}$

$3.0 \mathrm{~g}$

Stock solution 5

$\mathrm{H}_{2} \mathrm{O}$ (distilled)

$400 \mathrm{~mL}$

$\mathrm{KH}_{2} \mathrm{PO}_{4}$

$7.0 \mathrm{~g}$

Stock solution 6

$\mathrm{H}_{2} \mathrm{O}$ (distilled)

$400 \mathrm{~mL}$

$\mathrm{CaCl}_{2} \cdot 2 \mathrm{H}_{2} \mathrm{O}$

$1.0 \mathrm{~g}$

Trace element solution 1

$\mathrm{H}_{2} \mathrm{O}$ (distilled)

$400 \mathrm{~mL}$

$\mathrm{ZnSO}_{4} \cdot 7 \mathrm{H}_{2} \mathrm{O}$

$8.82 \mathrm{~g}$

$\mathrm{MnCl}_{2} \cdot 4 \mathrm{H}_{2} \mathrm{O}$

$1.44 \mathrm{~g}$

$\mathrm{MoO}_{3}$

$0.71 \mathrm{~g}$

$\mathrm{CuSO}_{4} \cdot 5 \mathrm{H}_{2} \mathrm{O}$

$1.57 \mathrm{~g}$

$\mathrm{CoNO}_{3} \cdot 6 \mathrm{H}_{2} \mathrm{O}$

$0.49 \mathrm{~g}$

$\mathrm{H}_{2} \mathrm{O}$ (distilled)

Trace element solution 2

$\mathrm{H}_{3} \mathrm{BO}_{3}$ $11.42 \mathrm{~g}$

Trace element solution 3

$\mathrm{H}_{2} \mathrm{O}$ (distilled)

EDTA $50.0 \mathrm{~g}$

$\mathrm{KOH}$

$31.0 \mathrm{~g}$

$\mathrm{H}_{2} \mathrm{O}$ (distilled)

Trace element solution 4

$\mathrm{FeSO}_{4} \cdot 7 \mathrm{H}_{2} \mathrm{O}$

Prepare each of the stock and trace element solutions listed above. Autoclave trace element solution 1 to dissolve. To prepare the final medium, combine $10 \mathrm{~mL}$ of each stock solution (1-6), $1 \mathrm{~mL}$ of each trace element solution (1-4), and $250 \mathrm{~mL}$ of soil extract $<\mathrm{R}>$ with sufficient distilled $\mathrm{H}_{2} \mathrm{O}$ to make a final volume of $1 \mathrm{~L}$. 
R. McNuff

Chalkley's Medium Plus Soil Extract

\begin{tabular}{llr} 
Solution & Reagent & Quantity \\
\hline Stock solution 1 & $\mathrm{NaCl}$ & $2.0 \mathrm{~g}$ \\
& $\mathrm{H}_{2} \mathrm{O}$ (distilled) & $100 \mathrm{~mL}$ \\
Stock solution 2 & $\mathrm{KCl}$ & $0.08 \mathrm{~g}$ \\
& $\mathrm{H}_{2} \mathrm{O}$ (distilled) & $100 \mathrm{~mL}$ \\
Stock solution 3 & $\mathrm{CaCl}_{2}$ & $0.12 \mathrm{~g}$ \\
& $\mathrm{H}_{2} \mathrm{O}$ (distilled) & $100 \mathrm{~mL}$
\end{tabular}

Prepare each of the stock solutions listed above. To prepare the final medium, combine $5 \mathrm{~mL}$ of each stock solution with $20 \mathrm{~mL}$ of soil extract $<\mathrm{R}>$ and sufficient distilled $\mathrm{H}_{2} \mathrm{O}$ to make a final volume of $1 \mathrm{~L}$.

\section{Soil Extract}

Obtain a quantity of fertile soil (i.e., humus-enriched soil) and air-dry it. Add 1 part soil to 2 parts tap water by volume, and autoclave. Allow to settle over a few days and decant the supernatant soil extract.

\section{REFERENCES}

Gabriel WN, McNuff R, Patel SK, Gregory TR, Jeck WR, Jones CD, Goldstein B. 2007. The tardigrade Hypsibius dujardini, a new model for studying the evolution of development. Dev Biol 312: 545-559. 


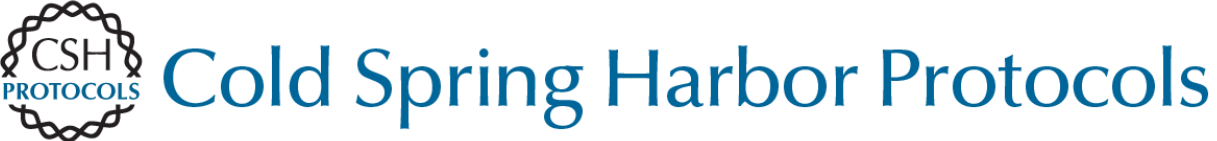

\section{Laboratory Culture of Hypsibius exemplaris}

Robert McNuff

Cold Spring Harb Protoc; doi: 10.1101/pdb.prot102319

\begin{tabular}{cc}
\hline $\begin{array}{r}\text { Email Alerting } \\
\text { Service }\end{array}$ & Receive free email alerts when new articles cite this article - click here. \\
\hline $\begin{array}{c}\text { Subject } \\
\text { Categories }\end{array}$ & $\begin{array}{c}\text { Browse articles on similar topics from Cold Spring Harbor Protocols. } \\
\text { Emerging Model Organisms (325 articles) } \\
\text { Laboratory Organisms, general (924 articles) }\end{array}$ \\
\hline
\end{tabular}

